\title{
An Analysis of Grammatical Errors on Speaking Activities
}

\author{
Merlyn Simbolon \\ Universitas Palangkaraya \\ merlyn.simbolon@gmail.com
}

\begin{abstract}
This study aims to analyze the grammatical errors and to provide description of errors on speaking activities using simple present and present progressive tenses made by the second year students of English Education Department, Palangka Raya University. The subject for this study was 30 students. This research applied qualitative research to describe the types, source and causes of students' errors taken from oral essay test which consisted of questions using the tenses of simple present and present progressive. The errors were indentified and classified according to Linguistic Category Taxonomy and Richard's classification, well as the possible sources and causes of errors. The findings showed that the errors made by students were in 6 aspects; errors in production of verb groups, errors in the distribution of verb groups, errors in the use of article, errors in the use of preposition, errors in the use of questions and miscellaneous errors. In regard to resource and causes, it was found that intra-lingual interference was the major source of errors $(82.55 \%)$ where overgeneralization took place as the major cause of the errors with total percentage of $44.71 \%$.
\end{abstract}

Keywords: grammatical errors, speaking skill, speaking activities

Generally, to be a professional English teacher someone should have good mastery in four language skills: listening, speaking, reading, and writing. These four language skills are integrated to make the communicative competence. Therefore, each of the skills should be considered as equally important to be mastered. Slightly different from two other skills of English, speaking and writing enable people to voice out them in a communication. This is a very fundamental reason of why they should be presented in appropriate sentence structure, based on the situation where the communication occurs and the main interest of the speaker or writer expressing their ideas in order to give comprehension toward the speakers or listeners on what they intend or emphasize to convey a listeners or a reader's toward a situation and context of the utterances will help him get a comprehension. In the same opinion, Eggins (2004) stated that speaking and communication in the particular situation at particular time. Without such context, language may lose its meaning.

Hence, in learning a language one should know how language works (language usage) and how to learn to use it (language use). It is the same case as learning musical instruments, a student who has been taught a lot of grammar but cannot use the language is because it is the same as a guitarist who has learnt a lot about harmony but cannot play the guitar. 
The student's achievement therefore cannot be only judged through how much he knows but also how well he can perform it in public. Based on observation conducted in English Education Department, especially in Speaking Subject, it was found that common and complex problems happened to the students in speaking English properly. Actually, the students are required to have mastered English grammar well, so they can go further into advanced English conversations. Contradictory with the expectation, it is found that there are still several aspects of speaking skill which become the obstacles for the students, such as grammar, vocabulary appropriateness, pronunciation and discourse management. Moreover grammar consists of a lot of differences between students' native language and English particularly when it comes to tenses. The students still faced a lot of difficulties in using tenses and tenses are generally still a big problem for Indonesian students as it is stated that Indonesian people do not recognize language structure as it is in English and these differences contribute to difficulties for them to master English (Tarigan \& Tarigan, 1990:56). However, the fact that tense is a basic component in speaking and writing could not be argued till the end of the day. Meanwhile, tenses are very crucial; it cannot be used both in spoken and written if the tenses are not mastered well.

There has been a research conducted by Nzama (2010) which is similar to this research. His research was to determine learner errors in both rural and urban schools. The first aim of his research was to determine through literature the types of errors and their probable causes. The second aim was to conduct an investigation into errors committed by learners and experienced by educators from learners. The questionnaires were used to find out whether factors such as lack of resources such as libraries, learning material, under qualification in English as a subject, lack of training in the structure of English and other factors had any influence in the committing of errors by learners. In terms of factors associated with errors, the most common factor to which all educators responded as a causal factor was the lack of facilities, among others, was the shortage of libraries and library books in cases where there are libraries. One other factor which was prominent was the lack of training in the structure of English as a subject.

From Nzama's (2010) research above, the researcher was interested to investigate similar research on error analysis committed by EFL learners. It is believed that there should be an analysis undertaken to know what errors are commonly made by the students in term of tenses while the students are speaking in English in Speaking 2 class since it requires students to use various grammars correctly, because by doing so, the lecturers will know and he can solve it for better men in the future as well as help the students to improve their ability in that particular aspects. Concerning the crucial existing errors, a research in this case is important in order to describe the types of grammatical errors on speaking made by the students together with their sources and causes of errors with the topic of an analysis of grammatical errors on speaking activities made by the students of English Education Department of 
Palangka Raya University. The research is conducted within the problems as follows: "(1) What types of errors are made by the students in using simple present and present progressive tenses when they are conducting speaking activities? (2) What are the sources of the errors? and (3) What are causes of the errors?"

When someone speaks to other person, there will be a relationship. The relationship itself is communication. When operating English spoken language, the speaker uses the system of grammatical choice. This system says that whenever the speaker produces a clause it must be only one of these three: declarative, as in "The baby is crying", interrogative as in "Is the baby crying?" and imperative "Cry". Spoken language is quite different from the written language where as in the above imperative "Cry!" the clause constituent is realized by the omission of the subject element, leaving only the predicator.

The word grammar has several meanings and there is no university accepted definition. Different experts define the term grammar differently. There is no fixed definition of grammar. Harmer (2004:12) defines grammar as the description of the ways in which words can change their forms and can be combined into sentence in that language. The expert said that is regulations or rules of how language is constructed and use in communication. People learn how to construct a good message based on the rules they have known and try to convey the message to the others. These rules are learned as grammar. Having known the definition of grammar, it is not hard to understand why grammar is useful and important. Without knowing the grammar of a language, one cannot be said to have learnt the language. Besides, it seems impossible to learn a language without learning the grammar because it tells us how to use the language.

The mechanism of grammar cannot be seen concretely, because it is rather abstractly represented in the human mind, but it is known that it is there because it works. One way of describing this mechanism is by means of a set of rules putting words together in certain ways which do not allow others. The meaning of a message conveyed by language has to be converted into words put together according to grammatical rules and these words are then conveyed by sounds.

However, speaking performance in the classroom can be achieved through six kinds of oral production (Brown, 2001:271- 274); they are (1) imitative that focusing on specific characteristic of language, (2) intensive, which is higher than imitative to practice some language aspects, (3) responsive which the goal is for short conversation to reply to teacher or student-initiated question or comment, (4) transactional or dialog for exchange specific information as the wider of responsive, (5) interpersonal or dialog for the purpose of maintaining social relationship, and (6) extensive for intermediate or advance level for the purpose or monologues, such as oral reports, summaries or oral report. In this case, a teacher should realize the characteristics of his/her students, so that this teacher can apply the speaking task properly. In the reality, speaking in classroom always contain mistakes or errors.

As a learner, making errors in language process is very common. It 
involves the making of mistakes and errors. Errors help the learners to establish the closer and closer approximations to the system of the target language. Brown (2001) stated, "...by gradual process of trial and error and hypothesis testing, the learner slowly and tediously succeeds in establishing closer and closer approximations to the system used by native speakers of the language. In a specific case of English learning, Indonesian students get problems in learning English because there are many differences between Indonesian and English in terms of grammar, vocabulary, etc.

According to Corder in Richards (1990) noted that errors "could be significant in three ways: they provided the teacher with information about how much the learned had learnt, they provided the researcher with of evidence of how language was learnt, they served as devices by which the learned discovered the rules of the TL.

An error is a systematic deviation, when a learner has not learnt something correct of a language and consistently "gets it wrong". When a learned of English as a second or foreign language makes an error systematically, it is because he has not learnt the correct form. On the other hand, there is inconsistent deviation we shall call it a mistake. Sometimes the learner "gets its right" but sometimes, he makes a mistake and uses the wrong form. Errors are significant to the learner because they provide evidence of the existence of an interlanguage. Mistake, on the other hand, are not significant to the learner. The difference between "mistake" and "errors" are as follows: a mistake is a performance error that is either a random guess or a "slip", in that it is a failure utilize a known system correctly.

From the definition above, the writer concludes that a mistake is something made by someone unconsciously. He/she already knows the rules. And he/she can fix it. On the other hand, an error is something that is made by a learner unconsciously, and he/she does not know the rules, and he/she cannot fix the error he/she makes either.

The linguistic category taxonomy is used as a reporting tool which organizes the errors that will be collected. It describes the errors provided by other taxonomies. For example, if researches have classified their errors as interlingual and developmental, they often additionally report the linguistic categories into which these major error types fall, e.g. developmental errors in the auxiliary, in the noun phrase, in the complement system; interlingual errors in phonology, in word order, and in vocabulary.

Furthermore, the classification of grammatical errors based on surface strategy taxonomy can be divided into (1) omission, (2) additions, misinformation, (4) misordering. Here are the classifications of errors according to surface strategy taxonomy (Dulay, et al., 1982:150).

While, grammatical errors based on comparative taxonomyare yielded into two major categories in this taxonomy: development errors (errors similar to those made by children learning the target language as their first language as in the auxiliary, in the noun phrase, in the complement system. Take, for example, the following utterance made by an 
Indonesian child learning English) and interlingual errors (errors simply refer to foreign language errors that reflect native language structure, regardless of the internal processes or external conditions that spawned them which are found in phonology, in word order, and in vocabulary).

Another classification comes from Richards (1990). He makes six classifications of error his laborious investigation. The examples of errors made will be taken from second and foreign language learners of English from widely linguistic background. He recognized the existence of the first language influence on the learners, but in this context ignores them. These are referred to as intralingual and developmental errors. Besides reflecting the learners' inability to separate two languages, the intralingual and developmental errors also reflect the learner competence at a particular stage and illustrate some of the general characteristics of language acquisition.

The general characteristic of language acquisition are overgeneralization, incomplete application of the target language rule, failure to learn condition under which rule apply, and the development of the false concept hypothesized. He explained that the intralingual and development errors originate from he learns English and describe the strategy by a second or foreign language learned acquires the language being learnt.

According to Richard's study (1990) the classification of the intralingual and development errors include: (1) Errors in the production of verb groups, (2) errors in the distribution of verb groups, (3) miscellaneous errors, (4) errors in the use of preposition, (5) errors in the use of articles, and (6) errors in the use of question.

Related to the explanation of the errors classification above, Richard's (1990) classification is used for the analysis of errors. The reason for using Richard's (1990) classification is based on his argument, in his laborious study. He maintains that the sample of errors that are representative of the sort of errors that might be happened from anyone learning English as a foreign language. They are typical of systematic errors of speakers of a particular mother tongue. Since the students at English Education Department of University of Palangka Raya are from various regions, the writer cannot easily specify his study based on every single particular mother tongue but will generalize their mother tongue into Indonesian. The reason of doing this way is because the writer cannot easily analyze the errors using case by case basis. In addition, it is also because the students have been accustomed to speaking Indonesian since they were kid and thinking through Indonesian in term of language learning.

Therefore, the sources and causes of errors for students are mostly because of the differences between the two languages (first language and foreign language). The difficulty may cause some errors in students' works. According to Richard's (1990) opinions, the main sources of errors are the interferences from native language (interlingual interference) and interference coming from the language being learnt, i.e. Indonesia students who get accustomed to using Indonesian sentence pattern that is different from the English 
language. The difficulty may cause some errors in students work.

Interlingual transfer errors, as Richard's (1990) points out, are popular among second language learners. Those are errors caused as a result of the "characteristics of one language are being carried into another popular language" (Richards, 1990:6). To put it in another way, learners have "carried the habits if his mother tongue into the second language" they are striving acquire. Thus, this type of errors is very diverse in form and manifestation as English second language learners from different cultures and settings will commit different errors of this type. Also, learners of different cultures have different modes of paragraph patterns. As a result, there is likelihood that they will transfer their mother tongue paragraph pattern into target language one.

Intralingual transfer, on the other hands, is the error sources that extend beyond just interlingual errors in learning a foreign language. It is now clear that intralingual transfer (within the target language itself) is a major factor in foreign language learning. Researchers have found that the early stages of language learning are characterized by a predominance of interference (interlingual transfer), but once learners have begun to acquire parts of the new system, more and more intralingual transfergeneralization within the target language rules and exceptions are primary acted as causes of errors. It is stated that "intralingual errors occur when first language does not have a rule, which foreign language has, but the learned applies a foreign language rules, producing an error (Tarigan, 1990)".
The other causes and sources of errors are overgeneralization, ignorance of rule restriction, incomplete application of rules, and false concept hypothesized (Richards, 1990). Overgeneralization which is caused by the extension of the target language rules to areas where they do not apply. The learner creates a deviant structure on the basic of his experience of other structure in the target language, perhaps due to superficial similarities that will be misleading and inapplicable. While, ignorance of rule restriction refers to the application of rules to context they do not have so that the restriction violates the rules exception. Incomplete application of rules relates to the learner's background language and the development of English language learning. The occurrence of errors represents the degree of the development of the rule required to produce acceptable utterance. The last is false concept hypothesized which are attributed to the faulty comprehension of distinction in the target language. The errors that are regarded as false concept hypothesized derive from faulty comprehension of distinction of target language. These are due to poor gradation of teaching materials.

\section{METHOD}

This research applied qualitative research because it was carried out in naturalistic settings, where researcher asked broad research questions to explore, interpret, and understand the social context (Lodico, et al., 2010). In this field, the researcher would like to investigate the students' grammatical errors on speaking English using simple present and present progressive tenses in 
Speaking 2 class by collecting the data from the result of oral essay test on speaking. Those data were taken from the second-year students of English Education Department of University of Palangka Raya in academic year 2014/2015. Thus, the data about simple present and present progressive tenses which were derived from students test result on speaking.

To collect the data, classroom observation was applied since it was trying to analyze the students' errors and the concern of this research is to find out the grammatical errors done by students in speaking by using Simple present and present progressive tenses. The researcher came to field, getting the students speaking through some oral questions and made recording, collecting their works, turning the results of their works into written form and analyzing them. In this way, the data were analyzed as objective as possible.

In processing the data, error analysis method was used as what Ellis (1994; 48) suggested the following steps to conduct an error analysis researches.

Table 1. Data Processing Procedures

\begin{tabular}{cll}
\hline No & \multicolumn{1}{c}{ Steps } & \multicolumn{1}{c}{ Details } \\
\hline 1 & $\begin{array}{l}\text { The collection of error } \\
\text { sample }\end{array}$ & $\begin{array}{l}\text { Collecting the test result which had been } \\
\text { conducted. The data of errors which were } \\
\text { obtained then identified according to the types } \\
\text { of errors made and their frequencies. }\end{array}$ \\
\hline 2 & Error classification & $\begin{array}{l}\text { Classifying the errors from the errors types to } \\
\text { their classifications. }\end{array}$ \\
\hline 3 & $\begin{array}{l}\text { Error explanation and } \\
\text { interpretation }\end{array}$ & $\begin{array}{l}\text { The activities consist of several steps: giving } \\
\text { explanation and interpretation of errors based } \\
\text { on their types along with their reconstruction as } \\
\end{array}$ \\
\hline 4 & Error evaluation & $\begin{array}{l}\text { The last step is to evaluate the causes and } \\
\text { predict the area of difficulties which potentially } \\
\text { brought some errors on the basis of frequency. }\end{array}$ \\
\hline
\end{tabular}

\section{FINDINGS AND DISCUSSIONS}

To present the description of the data obtained, the data were turned from recordings into script first. The second year students of English Education Department of University of Palangka Raya were required to answer a set of oral question in form of simple present and present progressive tenses. The number of the research subject was 30 . The test was conducted at the campus of English Education Department of University of Palangka Raya. Time allotted was 10 minutes to answer 10 questions. The results were transcribed in the following tables. 
Table 2. Test Results

\begin{tabular}{|c|c|c|c|c|}
\hline No & Types of Errors & $\mathbf{F}$ & $\%$ & Examples of Student's Answers \\
\hline 1 & Be + Infinitive & 10 & 6.58 & Are you activate you alarm? \\
\hline 2 & $\begin{array}{l}\text { Be Omitted before } \\
\text { Adjective }\end{array}$ & 7 & 4.60 & I cool when I speak English \\
\hline 3 & $\begin{array}{l}\text { Verb }+ \text {-ing for } \\
\text { Infinitive }\end{array}$ & 4 & 2.63 & $\begin{array}{l}\text { I usually attending speaking class once a } \\
\text { week }\end{array}$ \\
\hline 4 & $\begin{array}{l}\text { Past tense for } \\
\text { Infinitive }\end{array}$ & 4 & 2.63 & We had good lecturers at campus \\
\hline 5 & $\begin{array}{l}\text { Be Omitted before } \\
\text { verb +-ing }\end{array}$ & 15 & 9.87 & I studying English speaking now \\
\hline 6 & $\begin{array}{l}\text { Be+ Infinitive for be } \\
+ \text { verb +-ing }\end{array}$ & 4 & 2.63 & What book are you read now? \\
\hline 7 & $\begin{array}{l}\text { Be }+ \text { Verb +-ing } \\
\text { for Be }+ \text { Past } \\
\text { Participle }\end{array}$ & 4 & 2.63 & The lecture is teaching by Mr. Tampung \\
\hline 8 & $\begin{array}{l}\text { Do + Verb+-ing for } \\
\text { be + verb +-ing }\end{array}$ & 8 & 5.26 & What do you reading now? \\
\hline 9 & $\begin{array}{l}\text { Be }+ \text { Infinitive for } \\
\text { Infinitive }\end{array}$ & 9 & 5.92 & Our campus is have big buildings \\
\hline 10 & $\begin{array}{l}\text { Do omitted in } \\
\text { Interrogative } \\
\text { Sentence }\end{array}$ & 13 & 8.55 & $\begin{array}{l}\text { What time you usually get up in the } \\
\text { morning? }\end{array}$ \\
\hline 11 & $\begin{array}{l}\text { Addition of article } \\
\text { "the" }\end{array}$ & 6 & 3.95 & What kind of the book are you reading? \\
\hline 12 & $\begin{array}{l}\text { Omission of article } \\
\text { "the" }\end{array}$ & 7 & 4.60 & Can you wake up in the morning? \\
\hline 13 & $\begin{array}{l}\text { Wrong use of } \\
\text { preposition }\end{array}$ & 8 & 5.26 & I go to campus with motorcycle \\
\hline 14 & $\begin{array}{l}\text { Wrong word } \\
\text { choice }\end{array}$ & 6 & 3.95 & Can you louder the volume of the music? \\
\hline 15 & Literal Translation & 7 & 4.60 & I attend class speaking one time a week \\
\hline 16 & $\begin{array}{l}\text { S/es omitted for } 3^{\text {rd }} \\
\text { person singular }\end{array}$ & 4 & 2.63 & Our campus need more facilities \\
\hline \multirow[t]{2}{*}{17} & Misordering & 36 & 23.68 & $\begin{array}{l}\text { What you are reading now? } \\
\text { What listening are you? }\end{array}$ \\
\hline & Total & 152 & 100 & \\
\hline
\end{tabular}

Note: $\mathrm{f}=$ frequency 
The table above can be summed up as follows:

1. The greatest error is on type 17/ misordering (36 or $23.68 \%$ )

2. It is then followed by type $5 /$ be omitted before verb+ing (15 or $9.87 \%$ )

3. On the third and fourth position are type 10/ do omitted in interrogative sentence and $1 / \mathrm{Be}+$ Infinitive $(8.55 \%$ and $6.58 \%$ )

4. The number of errors is relatively small on type $3,4,6,7$, and 16 with $2.63 \%$ for each. From the data obtained on point 1, 2, and 3 above, it can be concluded that students' knowledge about the rules of pattern and restriction on constructing sentences using simple present and present progressive tenses in speaking activities is still poor. While the latter one describing small percentage of errors shows us that the students' ability in constructing sentence of the two tenses is pretty good.

\section{Data Analysis}

The error classification and their percentage then are analyzed based on Richard's classification as the following:

Table 3. The Classifications of Errors Based on Their Type

\begin{tabular}{cll}
\hline No & Code of Types of Errors & Classification of Errors \\
\hline 1 & Type $1,2,3,4,5,6,9$, and 16 & Errors in the Production of Verb Groups \\
\hline 2 & Type 7 & Errors in the Distribution of Verb Groups \\
\hline 3 & Type 11 and 12 & Errors in the Use of Article \\
\hline 4 & Type 13 & Errors in the Use of Preposition \\
\hline 5 & Type 8 and 10 & Errors in the Use of Question \\
\hline 6 & Type 14,15, and 17 & Miscellaneos Errors \\
\hline
\end{tabular}

Errors in the production of verb groups constitute the error in producing the correct and complete form of verb in pattern. In this case, these errors are mainly caused by overgeralization and incomplete application of rules. Errors in the distribution of verb groups refer to the errors in applying the correct pattern according to an appropriate context. It appears due to the false concept of hypothesized and ignorance of rule restrictions.

Errors in the use of article represent the errors in using correct or appropriate article in the sentence. The general causes are overgeneralization and less knowledge of the English articles. Errors in the use of preposition refer to the errors made in using appropriate preposition in the sentence. It is also commonly caused by overgeneralization and less knowledge about English preposition. Errors in the use of question conation constitute the errors in applying correct or appropriate auxiliary verbs used in the interrogative sentence. Incomplete application of rules, overgeneralization and ignorance of rule restrictions are main causes of these errors.

Miscellaneous errors are various errors in conjunction with translation, wrong order and choice of English words in term of the meaning of sentence in context as well as the omission or addition of certain language elements. In this study, the errors are misordering, wrong 
word choice and literal translation. Those errors are generally caused by interlanguage interference, overgeneralization, and incomplete application of rules and ignorance of rule restrictions. The classifications of the errors above can be clearly seen together with their frequency and percentages in the following table:

Table 4. The Classification of Errors and Their Percentages

\begin{tabular}{clcc}
\hline Code & \multicolumn{1}{c}{ Classification } & Frequency & Percentage \\
\hline A & Errors in the Production of Verb Groups & 57 & 37.50 \\
\hline B & Errors in the Distribution of Verb Groups & 4 & 2.63 \\
\hline C & Errors in the Use of Article & 13 & 8.55 \\
\hline D & Errors in the Use of Preposition & 8 & 5.26 \\
\hline E & Errors in the Use of Question & 21 & 13.81 \\
\hline F & Miscellaneous Errors & 49 & 32.24 \\
\hline \multicolumn{4}{c}{ Total } \\
\hline
\end{tabular}

The table above proves that the highest error is in classification A /errors in the production of verb groups (frequency $=57$ or $37.50 \%$ ). The second one is classification $\mathrm{B} /$ errors in the Distribution of Verb Groups (frequency $=$ 49 or $32.24 \%$ ). It is then followed by the classification E/ errors in the use of questions on the third rank (Frequency $=$
21 or $13.81 \%)$. The fourth belongs to classification $\mathrm{C}$ /errors in the use of article (Frequency $=13$ or $8.55 \%$ ) and the fifth one is in classification $\mathrm{D} /$ errors in the use of preposition (Frequency $=8$ or $5.26 \%$ ). The smallest errors are found in classification B/errors in the Distribution of Verb Groups (Frequency $=4$ or $2.63 \%$ ).

\section{Error Explanation and Interpretation}

\section{Classification A or Errors in the Production of Verb Groups}

Table 5. Errors in the Production of Verb Group

\begin{tabular}{|c|c|c|}
\hline No & Example of Errors & Reconstruction \\
\hline $\mathrm{A}$ & Are you activateyour alarm? & - Replace are with $\underline{\text { do }}$ \\
\hline B & I cool when I speak English & -Add am before cool \\
\hline $\mathrm{C}$ & $\begin{array}{l}\text { I usually attending speaking class once } \\
\text { a week }\end{array}$ & $\begin{array}{l}\text {-Remove Ing after infinitive } \\
\text { attend }\end{array}$ \\
\hline $\mathrm{D}$ & We had good lecturers at campus & -Substitute had to have \\
\hline $\mathrm{E}$ & I studying English speaking now & -Add am before studying \\
\hline $\mathrm{F}$ & What book are you readnow? & -Add ing after read \\
\hline
\end{tabular}

From the example of students errors above, it is proven that students made various errors in production of verb, such as constructing the infinitive after be (f), omitting be before adjective (b), omitting Verb+-ing after Be (a), using Verb+-ing in simple present tense (c), using past tense instead of infinitive (d), and 
omitting be before Verb+-ing (e). They show us that the students do not know $=\mathrm{W}$ the rules of constructing sentence in simple present and present progressive tense properly.

\section{Classification B or Errors in the Distribution of Verb Groups}

Table 6. Errors in the Distribution of Verb Groups

\begin{tabular}{cll}
\hline Code & \multicolumn{1}{c}{ Example of Errors } & \multicolumn{1}{c}{ Reconstruction } \\
\hline A & The Lecture is teaching by Mr. Tampung & $\begin{array}{l}\text { Replace Teaching with being } \\
\text { taught }\end{array}$ \\
\hline B & $\begin{array}{l}\text { The music which is listening by my } \\
\text { brother is Pop }\end{array}$ & $\begin{array}{l}\text { Replace listening with being } \\
\text { listened }\end{array}$ \\
\hline
\end{tabular}

Paying attention to the examples above makes us realize the students en counter complex problem in changing the verb stem. They still do not know the rules of forming and using past and present participle properly. They do not change the present participle into past participle and add being when they construct passive voice of present progressive tense.

\section{Classification C or Errors in the Use of Article}

Table 7. Errors in the Distribution of Verb Groups

\begin{tabular}{ccc}
\hline No & Example of Errors & Reconstruction \\
\hline A & What kind of the book are you reading ? & Remove the before book \\
\hline B & Can you make up in morning ? & Add the before morning \\
\hline
\end{tabular}

The errors above show that the have crucial meaning. Thus, they tend to students make the use of article in omit or add unnecessarily article "the" in sentences for granted since they do not a sentences.

\section{Classification D or Errors in the Use of Preposition}

\section{Table 8. Errors in the Distribution of Preposition}

\begin{tabular}{cll}
\hline No & \multicolumn{1}{c}{ Example of Errors } & \multicolumn{1}{c}{ Reconstruction } \\
\hline A & I go to campus with motorcycle & Substitute with to by \\
\hline B & I attend English speaking once at a week & Replace $\underline{\text { at with } \underline{\text { in }}}$ \\
\hline C & I attend the class $\underline{\text { in speaking 2 }}$ & Replace $\underline{\text { in with of }}$ \\
\hline
\end{tabular}

The examples of errors above give insight description that the students are lacking of knowledge about the use of English preposition correctly and tend to over-generalize the use of prepositions. This is a common error made by Indonesian students due to differences of meaning between English and Indonesian. 
Table 9. Errors in the Use of Question

\begin{tabular}{cll}
\hline No & \multicolumn{1}{c}{ Example of Errors } & \multicolumn{1}{c}{ Reconstruction } \\
\hline A & What do you reading now? & Replace $\underline{\text { do }}$ with are \\
\hline B & $\begin{array}{l}\text { What time you usually get up in the } \\
\text { morning? }\end{array}$ & Add $\underline{\text { do before you }}$ \\
\hline
\end{tabular}

The findings inform that the students still have great problem in distinguishing the use of auxiliary verb in interrogative sentence for different type of tense. In addition, they also sometimes omit the auxiliary "do" in an interrogative sentence. It might be caused by the interlanguage factor since Indonesian does not recognize "To Be" as it is in English.

\section{Classification F or Miscellaneous Errors}

Table 10. Miscellaneous Errors

\begin{tabular}{|c|c|c|}
\hline No & Example of Errors & Reconstruction \\
\hline A & $\begin{array}{l}\text { Can you louder the volume of the } \\
\text { music? }\end{array}$ & Replace louder with turn up \\
\hline $\mathrm{B}$ & $\begin{array}{l}\text { I attend class speaking one time a } \\
\text { week }\end{array}$ & $\begin{array}{l}\text { Arrange the sentence: } \\
\text { I attend speaking class once a week }\end{array}$ \\
\hline $\mathrm{C}$ & What you are readingnow? & $\begin{array}{l}\text { Arrange the sentence: } \\
\text { What are you reading now? }\end{array}$ \\
\hline $\mathrm{D}$ & What listening are youto? & $\begin{array}{l}\text { Arrange the sentence: } \\
\text { What are you listeningto? }\end{array}$ \\
\hline $\mathrm{E}$ & $\begin{array}{l}\text { By Mr. Tampung the lectures is } \\
\text { taught }\end{array}$ & $\begin{array}{l}\text { Arrange the sentence: } \\
\text { The lecture is taught by Mr. } \\
\text { Tampung }\end{array}$ \\
\hline
\end{tabular}

Glancing at the errors above, such as wrong word choice, literal translation, and misordering let us know that the students still do not master the rules on applying the correct from of a sentences well. The direct translation of Indonesian sentence structure into English is clearly visible in this errors classification (example b). it is a frequent and inevitable problem faced by Indonesian students who learn English because they commonly translate sentence simply by using their source language. In this case, the students translated the sentence by picking up equal meaning words to those in their source language.

\section{Error Evaluation}

In regard to the errors explanation and interpretation previously, the writer then talks further about the sources and causes of errors made by the students in this part. The sources of errors in this study can be clearly seen in terms of intralingual and interlingual errors. 
The intralingual errors are shown in the use of overgeneralization, incomplete application of rules, ignorance of rule restrictions and false concept hypothesized. The interlingual errors can be seen in forms of word-to-word translation and wrong words choice. However, there are also some errors which cannot be categorized either as intralingualor interlingual errors. Those errors are mainly because of less knowledge on constructing the correct forms of sentence in form of simple present and present progressive tense. In order to provide clear description of the intralingual and interlingual errors, the writer presents the data of sources of errors and their causes in the following tables:

Table 11. Intralingual Errors Made by the Students on Constructing Simple Present and Present Progressive Tense

\begin{tabular}{clcc}
\hline No & Cause of Errors & Frequency & Percentage (\%) \\
\hline 1 & Overgeneralization & 55 & 44.71 \\
\hline 2 & Incomplete Application of Rules & 42 & 34.15 \\
\hline 3 & Ignorance of rule Restrictions & 24 & 19.51 \\
\hline 4 & False Concept Hypothesized & 2 & 1.63 \\
\hline & Total & $\mathbf{1 2 3}$ & $\mathbf{1 0 0}$ \\
\hline
\end{tabular}

The greatest errors in overgeneralization (Frequency $=55$ or $44.71 \%$ ) show that the students inability in forming the correct sentence. Differences of structure between English and Indonesian become major obstacle in this case. The overgeneralization deals with overgeneralizing the verb inflections, the use of article and preposition, simple present and present progressive pattern, and agreement between subject and verb or auxiliary verb.

The second largest errors belong to incomplete application of rules (Frequency $=42$ or $34.41 \%$ ). The existence of errors indicate incomplete grammatical structure which involve in the omission of be/being, omission of do in interrogative sentence in the two tense. The students seem like to ignore the situation of a sentence and eventually produce deviant structure as a result. In addition, the wrong word order is also typical error made by the students which make them fail to construct the correct word order.

The third greatest errors are due to the ignorance of rule restrictions (Frequency = 24 or $19.51 \%$ ). These errors are indicated by the existence of wrong verb after be being and do/does, and violation in agreement between subject and verb. It shows us that the students apply the rules to context where they do not.

The smallest number of errors are in term of false concept hypothesized (Frequency $=2$ or $1.63 \%$ ). These errors are merely produced by students who fail to comprehend and distinguish the use between simple present and present progressive tense. It is due to faulty comprehension of distinction in the target language. 
Table 12. Interlingual Errors Made by the Students on Constructing Simple Present and Present Progressive Tense

\begin{tabular}{clcc}
\hline No & \multicolumn{1}{c}{ Cause of Errors } & Frequency & Percentage (\%) \\
\hline 1 & Literal Translation/Word-to-word & 7 & 26.92 \\
\hline 2 & The Omission of Be/being & 15 & 57.69 \\
\hline 3 & $\begin{array}{l}\text { The Omission of s/es in for } 3^{\text {rd }} \\
\text { singular }\end{array}$ & 4 & 15.38 \\
\hline & Total & $\mathbf{2 6}$ & $\mathbf{1 0 0}$ \\
\hline
\end{tabular}

The largest errors are found in the omission of be being (Frequency $=15$ or $57.69 \%$ ). This is an inevitable error made by Indonesian student in learning English because Indonesian does not recognize to be a verb or an adjective. However, in English they are supposed to construct such pattern when they are using present progressive tense either in writing or speaking activities.

The second largest errors are caused by literal translation (Frequency $=7$ or $26.92 \%)$. These errors occur when the students attempted to translate the target language from their source language. It can be clearly seen word-to-word translation. In addition, the omission of s/es ending after infinitive for third person singular also becomes a little obstacle in this case. It is usually due to structure differences between Indonesian and English because Indonesian never recognizes such addition even though it comes through the third person singular. The conclusion on the finding of the sources of errors as follow:

Table 13. Sources of Student's Errors

\begin{tabular}{cccc}
\hline No & Source & Frequency & Percentage (\%) \\
\hline 1 & Inralingual Errors of Interference & 123 & 82.55 \\
\hline 2 & Interlingual errors of interference & 55 & 17.45 \\
\hline & Total & $\mathbf{1 4 9}$ & $\mathbf{1 0 0}$ \\
\hline
\end{tabular}

The table above proves that the intralingual errors or interference is the major source of errors made by the student of English Education Department of University of Palangka Raya in Academic Year 2012/2013 on constructing sentences in forms of simple present and present progressive tenses on speaking activities. These errors are mainly structural errors which are caused by the students' faulty comprehension on the context where such tense apply. In contrast, the interlingual errors or interference are relatively small compared to intralingual interference. These factors are usually derived from source language of the English learners.

It can be summarized that the students made errors in almost circumstances where their knowledge is less regarding the sentence pattern of simple present and present progressive tense. It is in line with Tarigan's (1990) statement that if the comprehension of students toward a language they are learning still lacks, the errors frequently occur, errors will diminish along with the increase of their comprehension. 


\section{CONCLUSION}

Based on the findings of students' grammatical errors on speaking activities using simple present and present progressive tenses, the writer then draws the conclusion. First, the greatest type of error is in the production of verb groups as it is described in table, the second goes to miscellaneous errors; the third is in the use of questions; the fourth rank belongs to the use of article; the fifth goes to the use preposition and the last rank goes to the distribution. Second, the sources of errors are divided into intralingual and interlingual interference where the intralingual errors or interference dominate the number of errors. Third, the cause of errors made by the students are basically derived from the source itself; intralingual and interlingual, where each source consist of some causes.

After conducting the research, it is found out some crucial problems confronted by the students, the problems are not only on the matter of constructing the acceptable pattern of simple present and present progressive tenses but also involve the basic knowledge of subject and verb agreement of auxiliary, verb inflection, the use of article and preposition, and confusion in picking up appropriate words. Hence, the problem should be considered important to overcome by appropriate solution, for instance is determining the appropriate teaching and learning techniques which may benefit the students to gain better comprehension.

\section{REFERENCES}

Brown, H. D. (2001). Teaching by principle: An interactive approach to language pedagogy ( $2^{\text {nd }}$ ed.). San Francisco: Longman

Dulay, H., Burt, M., \& Krashen, S. (1982). Language two. Great Britian: Oxford University Press.

Eggins, S. (2004). An introduction to systemic functional linguistics. New York: Continuum.

Harmer, J. (2004). How to teach writing. New York: Longman.

Lodico, M. G., Spaulding, D. T., Voegtle, K. H. (2010). Methods in educational research: From theory to practice $\left(2^{\text {nd }}\right.$ ed.). San Fransisco: Jossey-Bass, A Wiley Imprint.

Nzama, M. V. (2010). Error analysis: Study of errors committed by isiZulu speaking learners of English in selected schools. Unpublished Thesis. Zululand: University of Zululand (Online), (http://uzspace.uzulu.ac.za/handle/105 30/615, accessed on October 17, 2015).

Richards, J. C. (1990). Error analysis: Perspectives on second language acquisition. Routledge.

Tarigan, H. G. \& Tarigan, D. (1990). Pelajaran analisis kesalahan berbahasa. Bandung: Tarsito. 
